\title{
CHARACTERISTICS OF A DIET AND SUPPLEMENTATION OF AMERICAN FOOTBALL TEAM PLAYERS - FOLLOWING A FASHIONABLE TREND OR A BALANCED DIET?
}

\author{
Joanna Smarkusz' , Joanna Zapolska , Katarzyna Witczak-Sawczuk', Lucyna Ostrowska ${ }^{l}$
}

${ }^{1}$ Department of Dietetics and Clinical Nutrition, Faculty of Health Sciences, Medical University of Bialystok, Poland

\begin{abstract}
Background. American football is based on speed and strength efforts players forming both defensive and offensive units in the team. Players' diet's may differ with regard to the variety of physical efforts performed and their different nutritional needs.

Objective. The aim of the study was to evaluate a diet and the supplementation, including the comparison of both the defensive and offensive player's formations, which may constitute a background of sportsmen' balanced menus permitting them to achieve better sports results.

Material and methods. The study included 44 American football players ( 24 defensive, 20 offensive players). The study group completed a three-day-dietary recall containing the time of consumption as well as a questionnaire about a type and amount of supplements used, including questions of one or multiple choice.

Results. The mean age of defensive players was $25.1 \pm 5.8$ years, while of offensive players was $23.4 \pm 3.7$. The mean body mass equaled $101 \pm 15.6 \mathrm{~kg}$ vs. $88.7 \pm 22.2 \mathrm{~kg}$. The mean height of defensive players was $183.8 \pm 6 \mathrm{~cm}$ vs. $182.4 \pm 7.3 \mathrm{~cm}$ of offensive players. Offensive players consumed on average $2471.9 \pm 838.6 \mathrm{kcal} / 24 \mathrm{hs}$, whilst defensive players $3086.1 \pm 908.9 \mathrm{kcal} / 24 \mathrm{hs}$. The mean level of cholesterol level consumption equaled $667.81 \pm 300 \mathrm{mg}$ in defensive players, while $546.2 \pm 285 \mathrm{mg}$ in offensive players. Of energizing preparations, protein powder supplement and coffee were most frequently chosen by players.

Conclusions. Defensive unit players were characterized by higher consumption of certain nutritional components and more frequent diet supplementation. A too low caloric intakes well as water, vitamin D, carbohydrates and dietary fiber intake was observed in both units. A high intake of high level cholesterol products requires reduced consumption of saturated fatty acids and increased consumption polyunsaturated fatty acids.
\end{abstract}

Key words: diet, American football, team sport, nutrients

\section{STRESZCZENIE}

Wprowadzenie. Futbol amerykański będący sportem zespołowym, bazuje na wysiłkach szybkościowych i siłowych, zaś w skład drużyny wchodzą zawodnicy formacji defensywnej oraz ofensywnej. Sposób żywienia zawodników, może różnić się ze względu na różnorodność wykonywanych wysiłków fizycznych i odmienne potrzeby żywieniowe.

Cel. Celem pracy była ocena sposobu żywienia i suplementacji z uwzględnieniem porównania obu formacji zawodników: defensywnej oraz ofensywnej, która stanowić może podstawę do zbilansowania jadłospisów sportowców, umożliwiając im uzyskiwanie lepszych wyników sportowych.

Material i metody. W badaniu udział wzięło 44 zawodników futbolu amerykańskiego Lowlanders Białystok (24 formacji defensywnej oraz 20 ofensywnej). Grupa badana uzupełniła 3-dniowy dzienniczek żywieniowy z uwzględnieniem godzin spożycia, gramatury poszczególnych produktów/ posiłków oraz kwestionariusz ankiety dotyczący rodzaju oraz ilości stosowanych suplementów.

Wyniki. Średni wiek badanych zawodników defensywy wyniósł 25.1 \pm 5.8 lat, zaś formacji ofensywnej 23.4 \pm 3.7 . Średnia masa ciała była równa $101 \pm 15.6 \mathrm{~kg}$ vs. $88.7 \pm 22.2 \mathrm{~kg}$. Średni wzrost zawodników defensywy wynosił $183.8 \pm 6 \mathrm{~cm}$ vs. $182.4 \pm 7.3 \mathrm{~cm}$ u zawodników ofensywy. Gracze ofensywy przyjmowali średnio $2471.9 \pm 838.6 \mathrm{kcal} / \mathrm{dobę,} \mathrm{zaś} \mathrm{defensywy} 3086.1 \pm 908.9 \mathrm{kcal} /$ dobę. Średni poziom spożycia cholesterolu u zawodników defensywy wynosił $667.81 \pm 300 \mathrm{mg}$ zaś ofensywy $546.2 \pm 285 \mathrm{mg}$. Najczęściej wybieranymi przez zawodników były odżywki białkowe, a z preparatów energetyzujących - kawa.

Wnioski. Zawodnicy formacji defensywnej, charakteryzowali się wyższym spożyciem poszczególnych składników odżywczych oraz częstszym przyjmowaniem suplementów diety. W obu formacjach zaobserwowano zbyt niską energetyczność diety, podaż wody, witaminy D, węglowodanów i błonnika pokarmowego. Wysoka podaż produktów bogatych w cholesterol, wskazuje na konieczność redukcji spożycia nasyconych kwasów tłuszczowych i zwiększenie spożycia kwasów tłuszczowych wielonienasyconych.

Słowa kluczowe: dieta, futbol amerykański, sporty zespołowe, składniki odżywcze

*Corresponding author: Joanna Smarkusz, Department of Dietetics and Clinical Nutrition, Medical University of Bialystok, Mieszka I-go 4B Street, 15-054 Bialystok, tel: +48 88 1517141, e-mail: joannasmarkusz@wp.pl. 


\section{INTRODUCTION}

Team sport is the most popular sport discipline of the 20 century predominating in the world. Due to the characteristics of American football, its team contains both defensive and offensive unit players. Sportsmen involvement is enormous during a game or training, doing aerobics and speed efforts. An appropriate model of nutrition taking into consideration an increased intake of some nutrients, such as proteins, carbohydrates, minerals and vitamins is essential in this discipline. Properly personalized supplementation as well as biological regeneration are equally important. They contribute to sportsmen's achievements and improve the quality of regeneration [6]. Individual diets may differ regarding various physical efforts, different nutritional and supplemental needs. According to American Dietetic Association, Canada Dieticians and American College of Sports Medicine, a proper diet influences significantly the physical efficiency of sportsmen's organisms. A diet should be rationalized and adapted and customized to the type of physical activity [20].

The aim of the study was to evaluate American football players' diet and supplementation. The analysis of the study results will enable to obtain the information regarding dietary mistakes made by the American football players. This may lead to balancing sportsmen's proper menus allowing them to achieve better sports results.

\section{MATERIAL AND METHODS}

The study includes 44 players of American football team of Lowlanders Bialystok, training actively this sports discipline. A defensive unit consists of 24 players (54\%), while an offensive (attack) unit - 20 players $(46 \%)$.

The approval of the Bioethical Committee, Medical University of Bialystok, number R-I-002/496/2014 was obtained for the test. All participants have given their informed consent for participation in the research study. Every precaution was taken to protect the privacy of patients.

The study group completed a three-day-dietary recall designed on the grounds of a 24-hour review questionnaire, which provided anthropometric data as well as the information about frequency, quality and quantity of meals consumed during two working days and a day off. The consumption time, grammage of individual products, the amount of liquids were taken into consideration. A portion size was verified based on 'Album of photographs of products and dishes' published by Institute of Food and Nutrition in Warsaw [22]. Analyzing a questionnaire, the caloric values of individual meals and the content of essential nutrients and liquids were taken into consideration. Computer program Diet 5 developed by the Institute of Food and Nutrition was used for qualitative analysis. The norms of daily calorie intake were established for healthy men in the age interval 19-30, at the PAL-physical activity level equaled 1.75 [12].

Due to lack of randomized studies determining precisely the daily intake level of basic nutrients for American football players, the studies referring to the team sport because of the similar characteristics of physical efforts were used in the discussion. The intake level of basic nutrients was compared to the norm for proteins [11], lipids [12], carbohydrates [18], minerals [12], vitamins [12], and liquids [15].

The survey questionnaire referring to the supplementation applied contained one-and multiplechoice questions. They concerned preparations used, their type, frequency, quantity and the way of administration.

The results were analyzed in the program STATISTICA 12.0 of StatSoft firm. Descriptive statistics was developed and an arithmetic mean, standard deviation, ranges of maximum and minimum values were calculated by means of this program. Chisquare Pearson and Mann-Whitney tests were used to calculate the results.

\section{RESULTS}

The mean age of the examined equaled $24.3 \pm 4.9$ years (16-40 years). In the defensive unit, the mean age was $25.1 \pm 5.8$ years, while $23.4 \pm 3.7$ years in the offensive unit. However, these values were not statistically significant.

In defensive players, the mean body mass was $101 \pm 15.6 \mathrm{~kg}$, and $88.7 \pm 22.2 \mathrm{~kg}$ in offensive players. The mean height of defensive players equaled $183.8 \pm 6 \mathrm{~cm}$, while of offensive players, $182.4 \pm 7.3 \mathrm{~cm}$. A statistically significant difference, $\mathrm{p}=0.02$, was determined only for the body mass of respective unit players.

The comparison of daily calorie intake and basic nutrients among players of an offensive and defensive unit was presented in Table 1. Offensive players consumed on average $2471.9 \pm 838.6 \mathrm{kcal} / 24 \mathrm{~h}$, which squared Estimated Average Requirement (EAR) only in $69 \%$, whereas defensive players, $3086.1 \pm 908.9 \mathrm{kcal} / 24 \mathrm{~h}$ ( $80 \%$ of EAR). These differences were statistically significant at the level of significance $\mathrm{p}=0.02$.

The mean consumption of protein was higher in players of a defensive unit, reaching $156.3 \pm 42.7 \mathrm{~g}$ (on average $1.6 \mathrm{~g} / \mathrm{kg}$ of body mass $/ 24 \mathrm{~h}$ ) than in players of an offensive unit, $127.3 \pm 37.7 \mathrm{~g}$ (on average $1.4 \mathrm{~g} /$ $\mathrm{kg}$ of body mass $/ 24 \mathrm{~h}$ ). The mean intake of vegetable protein was also higher in a defensive unit and equaled $39 \pm 15.5 \mathrm{~g}$. These results were statistically significant (Table 1.) 
Table 1. Comparison of the daily level of energy supply and basic nutrients among players of defensive and offensive formation

\begin{tabular}{|c|c|c|c|c|c|c|c|}
\hline \multirow{2}{*}{ Parameter } & \multicolumn{3}{|c|}{ Defensive $(n=24)$} & \multicolumn{3}{|c|}{ Offensive $(n=20)$} & \multirow{2}{*}{$\mathrm{p}$} \\
\hline & Average \pm SD & Min. & Max. & Average \pm SD & Min. & Max. & \\
\hline Energy value of the diet (kcal) & $3086.1 \pm 908.9$ & 1644 & 4517.7 & $2471.9 \pm 838.6$ & 1558.1 & 4602.7 & 0.02 \\
\hline EAR (\%) & $80.1 \pm 26.7$ & 45.7 & 131.6 & $68.9 \pm 23.9$ & 43.3 & 127.8 & 0.05 \\
\hline Protein $(\mathrm{g})$ & $156.3 \pm 42.7$ & 84.9 & 268.9 & $127.34 \pm 37.7$ & 78.1 & 218.0 & 0.02 \\
\hline Plant protein $(\mathrm{g})$ & $39 \pm 15.5$ & 10.7 & 76.2 & $30.1 \pm 12.1$ & 16.1 & 57.9 & 0.03 \\
\hline Animal protein $(\mathrm{g})$ & $113.3 \pm 38.7$ & 51.5 & 230.5 & $93.9 \pm 32.7$ & 55.4 & 182.3 & 0.07 \\
\hline Fat's (g) & $114 \pm 46.7$ & 44.2 & 220.4 & $85.0 \pm 41.5$ & 27.3 & 193.6 & 0.03 \\
\hline Saturated fat's (g) & $41.9 \pm 18.9$ & 14.8 & 93.3 & $29.7 \pm 12.6$ & 7.5 & 59.8 & 0.02 \\
\hline Mono-unsaturated fats (g) & $46.9 \pm 21.3$ & 14 & 91.1 & $33.2 \pm 15.7$ & 10.1 & 61.6 & 0.03 \\
\hline Poly-unsaturated fat's (g) & $16.3 \pm 7.0$ & 4.2 & 29.2 & $14.3 \pm 19.5$ & 4.1 & 93.6 & 0.01 \\
\hline Food cholesterol (mg) & $667.81 \pm 300$ & 241.5 & 1176.2 & $546.2 \pm 285$ & 209.4 & 1158 & 0.13 \\
\hline Carbohydrates (g) & $373.8 \pm 117.2$ & 209.8 & 604.4 & $317.8 \pm 123.3$ & 136.9 & 695.2 & 0.10 \\
\hline Simple carbohydrates (g) & $347.0 \pm 111.1$ & 192.7 & 575.2 & $295.9 \pm 119.6$ & 123.9 & 665.7 & 0.09 \\
\hline Fiber $(\mathrm{g})$ & $25.5 \pm 7.9$ & 10.3 & 44.6 & $21.4 \pm 6.9$ & 11.6 & 34.6 & 0.10 \\
\hline
\end{tabular}

Next the mean total lipids consumption and respective groups of fatty acids and food cholesterol were compared. The mean total lipid intake with a diet equaled $114 \pm 46.7 \mathrm{~g}$ (average $1.1 \mathrm{~g} / \mathrm{kg}$ of the body mass per 24 hours ) in a defensive unit, while $85 \pm 41.5 \mathrm{~g}$ (on average $0.95 \mathrm{~g} / \mathrm{kg}$ of the body mass per 24 hours) in a offensive unit, respectively. These differences were statistically significant $(\mathrm{p}=0.03)$. Defensive players also consumed more saturated acids $(41.9 \pm 18.9 \mathrm{~g})$, while offensive players consumed on average $29.7 \pm 12.6 \mathrm{~g}$. These differences were statistically significant $(\mathrm{p}=0.02)$. Defensive players consumed also more monounsaturated, of which mean level was $46.9 \pm 21.3 \mathrm{~g}$ in contrast to offensive players' mean consumption reaching the level of $33.2 \pm 15.7 \mathrm{~g}(\mathrm{p}=0.03)$. The mean consumption of polyunsaturated lipids was similar in both study groups and equaled: $16.3 \pm 7.0 \mathrm{~g}$ in defensive players and $14.3 \pm 19.5 \mathrm{~g}(\mathrm{p}=0.01)$ in offensive players. In both groups, a very high level of food cholesterol was reported: on average $667.81 \pm 300 \mathrm{mg}$ in defensive players and $546.2 \pm 285 \mathrm{mg}$ in offensive players. Maximum levels of this component intake were also high and equaled $1176.2 \mathrm{mg}$ in a defensive unit and $1158.4 \mathrm{mg}$ in a offensive unit.

Daily intake of carbohydrates and food fiber consumed with a diet was analyzed. The mean total consumption of carbohydrates was higher among defensive players than in offensive players, equaling on average $373.82 \pm 117.25 \mathrm{~g}$. Defensive players also consumed more assimilable carbohydrates and food fiber. The differences presented above were statistically insignificant.

Mineral components and vitamin D intake in a diet were analyzed statistically (Table 2). The higher consumption of all minerals and vitamin D was observed in defensive players with statistically significant differences regarding sodium and iron.

Table 2. Comparison of the average daily intake of selected minerals and vitamin D among the players of defensive and offensive formation

\begin{tabular}{|l|r|r|r|r|r|r|r|}
\hline \multirow{2}{*}{ Parameter } & \multicolumn{2}{|c|}{ Defensive $(\mathrm{n}=24)$} & \multicolumn{2}{c|}{ Offensive $(\mathrm{n}=20)$} & \multirow{2}{*}{ P } \\
\cline { 2 - 8 } & \multicolumn{1}{|c|}{ Average \pm SD } & \multicolumn{1}{c|}{ Min. } & \multicolumn{1}{c|}{ Max. } & Average \pm SD & \multicolumn{1}{c|}{ Min. } & Max. & \\
\hline Sodium (mg) & $5195.3 \pm 1650.1$ & 2624.4 & 8674.5 & $4061.2 \pm 1306.9$ & 2285.8 & 6057.9 & 0.01 \\
\hline alcium (mg) & $1043.1 \pm 769.9$ & 98.2 & 3031.2 & $847.5 \pm 547.3$ & 280.7 & 1911.7 & 0.34 \\
\hline Magnesium (mg) & $491.6 \pm 158.2$ & 169.3 & 759.3 & $429.1 \pm 170.1$ & 224.8 & 706.5 & 0.13 \\
\hline Iron (mg) & $19.1 \pm 10.5$ & 9.0 & 51.4 & $15.2 \pm 9.0$ & 8.6 & 41 & 0.05 \\
\hline Vitamin D (ug) & $4.6 \pm 2.5$ & 1.9 & 11.5 & $3.8 \pm 2.3$ & 0.9 & 8.8 & 0.19 \\
\hline
\end{tabular}

The mean consumption of liquids was another parameter assayed in the study. The mean daily intake was higher among defensive players $(1925 \mathrm{ml})$ than offensive players $(1750 \mathrm{ml})$. The differences were statistically insignificant $(\mathrm{p}=0.44)$.

The survey questionnaire aimed at evaluation of the kinds and frequency of diet supplementation among the sportsmen with $58 \%$ of defensive players and $65 \%$ of offensive players who declared consumption of vitamin and mineral supplements. More than $77 \%$ of players of both units continued supplementation for the whole year.

Sportsmen drank also energy drinks, enriched with vitamins or minerals. A total of $96 \%$ of defensive players and $90 \%$ of offensive players declared their consumption in the survey. These were not products 
chosen every day, but drank during training or competitions, several times in a month in the amount not exceeding 2 liters.

In the defensive and offensive unit, $83 \%$ and $65 \%$ of players consumed functional food, respectively. Some players used more than one type of functional food. Types of preparation with the division into units were presented in Table 3.

Of defensive players, $67 \%$ and $40 \%$ of offensive players took protein powder (differences close to statistical significance $(p=0.07))$. Protein- carbohydrates powder supplements (in which the ratio of carbohydrates to proteins is 1:1) and the type of Gainer (the ratio of carbohydrates to proteins is $4: 1$ ) were rarely chosen by players of units. Functional food of the Carbo type (carbohydrates) was slightly more frequently chosen by defensive players. Then sportsmen were asked about substances improving concentration. Defensive and offensive units were compared revealing statistically significant differences $(\mathrm{p}=0.02)$ in the regularity of their consumption among the players, which were presented in Table 4.

Table 3. Comparison of the frequency intake of sports nutrition supplements

\begin{tabular}{|l|c|c|c|c|c|}
\hline \multirow{2}{*}{\multicolumn{1}{c|}{ Type of supplement }} & \multicolumn{2}{c|}{ Defensive $(\mathrm{n}=24)$} & \multicolumn{2}{c|}{ Offensive $(\mathrm{n}=20)$} & $\mathrm{n}$ \\
\cline { 2 - 7 } & $\mathrm{n}$ & $\%$ & $\mathrm{n}$ & 40 & 0.07 \\
\hline Protein supplements & 16 & 67 & 8 & 10 & 0.44 \\
\hline Protein and carbohydrate suppl. & 1 & 4 & 2 & 10 & 0.84 \\
\hline Gainer type supplements & 2 & 8 & 7 & 33 & 0.90 \\
\hline Carbo type supplements & 8 & 35 & 7 & & \\
\hline
\end{tabular}

Table 4. Comparison of the frequency of intake of supplements to improve concentration

\begin{tabular}{|c|c|c|c|c|c|}
\hline \multirow{2}{*}{ Frequency of intake } & \multicolumn{2}{|c|}{ Defensive $(n=24)$} & \multicolumn{2}{|c|}{ Offensive $(n=20)$} & \multirow{2}{*}{$\mathrm{P}$} \\
\hline & $\mathrm{n}$ & $\%$ & $\mathrm{n}$ & $\%$ & \\
\hline Regularly & 5 & 21 & 4 & 20 & 0.02 \\
\hline Irregularly & 7 & 29 & 2 & 10 & 0.02 \\
\hline Rarely & 11 & 46 & 6 & 30 & 0.02 \\
\hline I do not use & 1 & 4 & 8 & 40 & 0.02 \\
\hline
\end{tabular}

It was demonstrated that $46 \%$ of defensive players rarely took these preparations, while only $21 \%$ did this regularly. Most offensive players (40\%) did not use these preparations, while only $20 \%$ took them regularly. The players were also asked about the type of preparations consumed to improve concentration. The results obtained were shown in Table 5 .

Table 5. Comparison of the type of intake of supplements to improve concentration

\begin{tabular}{|l|c|c|c|c|c|}
\hline \multirow{2}{*}{ Type of supplement } & \multicolumn{2}{|c|}{ Defensive $(\mathrm{n}=24)$} & \multicolumn{2}{|c|}{ Offensive $(\mathrm{n}=20)$} & \multirow{2}{*}{$\mathrm{P}$} \\
\cline { 2 - 6 } & $\mathrm{n}$ & $\%$ & $\mathrm{n}$ & 45 & 0.37 \\
\hline Coffee & 14 & 58 & 9 & 5 & 0.26 \\
\hline Guarana & 0 & 0 & 1 & 25 & 0.05 \\
\hline Energy drinks & 13 & 54 & 1 & 5 & 0.22 \\
\hline Other & 4 & 17 & 5 & & \\
\hline
\end{tabular}

Interestingly, when comparing the types of substances improving concentration, the differences revealed referred only to energy drinks. As many as $54 \%$ of defensive players and only $25 \%$ of offensive players drank these drinks (statistically significant differences $\mathrm{p}=0.05$ ). Defensive players more often chose coffee, though these differences were statistically insignificant.

\section{DISCUSSION}

A properly balanced diet and supplements applied in justified cases influence beneficially the results achieved by American football players. Additionally, since a diet affects the players' body composition, it should be personalized and adjusted to the type of training and competition. This plays a significant role in forming players' cardiovascular and respiratory capacity [1].

The food players of both offensive and defensive units consumed did not provide the necessary amount of calories at the level required according to the norm of Estimated Average Requirement [12]. The offensive unit players providing the energy value at the level of $2471.9 \pm 838.9 \mathrm{kcal}$ with a diet covered energy requirements only in $69 \%$ of EAR norm, while the defensive unit players in $80 \%$ (3086.1 1908.9 $\mathrm{kcal} / 24 \mathrm{hs})$. Taking into consideration intensive trainings, a daily energy intake should reach about 3850 $\mathrm{kcal}$ in a defensive unit and $3600 \mathrm{kcal}$ in an offensive 
unit. A similar conclusion was drawn in the study of Borrows et al. in 2016 year, assessing the consumption of individual nutritional components among 25 rugby players [3]. In this study, a mean energy value of a diet equaled $2450 \mathrm{kcal}$, which was similar to the value obtained in our study. Since rugby players were preparing to a season, a coefficient of physical activity was established at the Physical Activity Level (PAL)= 1.4 (compared to 1.75 in our study). The conclusion can be drawn that a similar calorie value of players' diet resulted from a similar amount and intensity of trainings. Players' diet should be personalized with regard to requirements depending on their position in the playing field and physical efforts undertaken as well as the kind of a training season [7].

A total protein, vegetable and animal protein consumption is essential in sportsmen' diet, mainly, when trainings are based on strengths exercises. The proper amount of this component influences the regeneration of the muscle fibers damaged during intensive training or competition. In our study, players more frequently chose food products providing animal than vegetable protein. The mean total protein consumption was higher in a defensive unit $(156.3 \pm 42.7$ $\mathrm{g} / 24 \mathrm{hs})$ than in a offensive unit $(127.34 \pm 37.7 \mathrm{~g} / 24$ hs). The studies carried out by Berning in 2015 year showed the mean protein consumption of 131-139 $\mathrm{g}$ in the group of American football players [2], which was a slightly lower than the values obtained in our study. American football players should consume on average $1.6-1.7 \mathrm{~g} / \mathrm{kg}$ of the body mass. Our results indicate that a protein intake in grams per kilogram of the body mass was $1.6 \mathrm{~g}$ in defensive players, whereas only 1.4 $\mathrm{g}$ in offensive players. Defensive players' requirement of total protein over their body mass and the type of physical efforts performed should equal about 172 $\mathrm{g}$ /day, while offensive players required about $151 \mathrm{~g} /$ day [11]. Thus, as our study showed the norm for this component requirement was not covered. The players' menus should be varied complying the food products being the source of vegetable protein simultaneously adjusting animal protein intake with regard to players' individual requirement.

Lipids were another nutrient analyzed in the study. The consumption of total lipids, saturated, monounsaturated fatty acids and cholesterol was higher in a defensive unit than in an offensive unit. Total lipid consumption per a kilogram of the body mass equaled on average $1.1 \mathrm{~g}$ in defensive players, while $0.95 \mathrm{~g}$ in offensive players. Similar values were reported in the study of Potgieter et al. from 2014 year carried out in the group of rugby players [19]. This study showed that the mean consumption of lipids was $97 \mathrm{~g} / 24 \mathrm{hs}$, which constituted about 1g/ $\mathrm{kg}$ of the players' body mass. When comparing our and Potgieter's et al. study results, it was found that the data obtained were very close and consumption of lipids was at the similar level oscillating within a proper range in these players. However, the level of cholesterol consumption is disturbing. In our study, its mean level was $667.81 \pm 300 \mathrm{mg}$ in defensive players and $546.2 \pm 285 \mathrm{mg}$ in offensive players. Its maximum consumption per day was $1176.2 \mathrm{mg}$ and $1158 \mathrm{mg}$ in both groups, respectively. In the study from 2014 year mentioned above, the mean daily consumption of food cholesterol was $766.3 \pm 371.8 \mathrm{mg}$, which was very close to the results presented in our study. In both studies, this component consumption was very high, significantly exceeding the norm of $300 \mathrm{mg} / 24$ hs [12]. Planning players 'diet, the intake of products with cholesterol and saturated fatty acids should be personalized. A healthy 19-30 year-old man, physically active at the coefficient of PAL $=1.75$ should consume on average $120 \mathrm{~g}$ of lipids in total per 24 hours (the body mass about $90 \mathrm{~kg}$ ). At the same time, each player should have the intake of mono and polyunsaturated acids personalized, which may protect against cardiovascular diseases [12].

Carbohydrates should be the main source of energy in a rational personalized diet of healthy people. This component is a basis of a sportsman's properly balanced diet, especially, when he does endurance sport, where a level of glycogen in the body is very important.

In our study, defensive players consumed significantly higher amount of carbohydrates $(373.8 \pm 117.2 \mathrm{~g})$ compared to offensive players $(317.8 \pm 123.3 \mathrm{~g})$, though still too low in comparison to the norm. In our study, consumption of carbohydrates was about $3.7 \mathrm{~g} / \mathrm{kg} / \mathrm{bw} / 24 \mathrm{hs}$ in defensive players and about $3.6 \mathrm{~g} / \mathrm{kg} / \mathrm{bw} / 24 \mathrm{hs}$ in offensive players. In Tooley's et al. study [23], diets of ten professional rugby players were analyzed, defining the mean consumption of total carbohydrates as $476,77 \mathrm{~g}$ (about $4.9 \mathrm{~g} / \mathrm{kg}$ of a player's body mass). These levels were higher than in our study. According to American College of Sports Medicine, carbohydrates intake should be about 6-10 g over a kilogram of the body mass in 24 hours in a diet of people active physically, especially, taking into account such a discipline like American football. The ratio of carbohydrates intake to proteins intake should be $4: 1$ or $3: 1$. The results of our study showed that consumption of carbohydrates was insufficient, which might have caused a worse response to training or faster fatigue [18].

In many sports, food fiber consumption can be improper due to intestinal disorders caused by its excess. Players being afraid of diarrhea give up the products with fiber. In our study, the mean daily consumption of this component was $25.5 \pm 7.9 \mathrm{~g}$ in defensive players and $21.4 \pm 6.9 \mathrm{~g}$ in offensive players. In the study referring to fiber consumption among rugby players, 
the daily mean consumption of food fiber equaled $36.4 \pm 8.1 \mathrm{~g}$ [14]. These were obviously higher levels than those obtained in our study. Based on this data, it can be concluded that fiber consumption should be higher, especially, in the offensive unit. Players should be educated about the products providing fiber and its proper personalized amount adjusted to training seasons and competition.

An adequate level of calcium, magnesium and iron consumed is necessary for a sportsman's organism to function properly. Calcium affects beneficially the bone mass formation and the calcium-phosphorous product in the body. Magnesium with potassium prevents from cumbersome and frequent cramps (especially in lower extremities) occurring after trainings. Iron, a main component, responsible for a proper structure and functions of erythrocytes, prevents from microcytic anemia.

In our study, the daily mean consumption of minerals covered the norm of EAR. The mean consumption of calcium was $1043.1 \pm 769.9 \mathrm{mg}$ among defensive players and 847.5 $\pm 547.3 \mathrm{mg}$ among offensive players. The norm of EAR for this component equals $800 \mathrm{mg}$ for healthy and physically active men aged 19-30 years [12]. The daily mean consumption of magnesium was $491.6 \pm 158.2 \mathrm{mg}$ in defensive players and $429 \pm 170 \mathrm{mg}$ in offensive players. These were levels covering completely the requirement compared to the norm of EAR for this product, equaling $330 \mathrm{mg}$ [12]. In our study, players exceeded significantly the norm of EAR for iron consumption, $6 \mathrm{mg}$ [12], with the mean consumption of $19 \pm 10.5 \mathrm{mg}$ in the defensive unit and $15.25 \pm 9 \mathrm{mg}$ in the offensive unit. Taking into consideration these results, the conclusion can be drawn that the requirement for minerals listed above was covered in sportsmen's menus. The increased level of magnesium and iron consumption exceeding the norm may result from consuming the fortified and functional food.

However, sportsmen's menus are not always balanced with regard to the content of mineral components. In the study carried out among rugby players, Imamura et al. showed different results; the mean consumption of calcium was $668 \pm 268 \mathrm{mg}$, magnesium - $311 \pm 81 \mathrm{mg}$ and iron - $8.7 \pm 2.9 \mathrm{mg}$ [10] Obviously, these were lower levels than those obtained in our study and not covering the recommended amount. This could result from an improperly balanced diet, poor in the sources of these components or lacking the fortified or functional food usually consumed by sportsmen.

American football players' intensive physical efforts may cause deficiency of D vitamin in the body. These sportsmen not usually consuming D- vitaminrich products, training and competing indoors, which makes $\mathrm{D}$ vitamin production in the skin impossible, are, especially, prone to this condition [13]. In our study, the mean consumption of vitamin $\mathrm{D}$ in a daily diet was $4.6 \pm 2.5 \mu \mathrm{g}$ in defensive players, while $3.8 \pm 2.3 \mathrm{ug}$ in offensive players. Our study showed that players 'menus should be varied, containing D vitamin rich products, due to significantly lower its consumption compared to the norm of EAR equaling $10 \mu \mathrm{g} / 24 \mathrm{hs}$ [12]. Garrido obtained similar results in the study assessing vitamin $\mathrm{D}$ intake in a diet of soccer players [9]. The consumption of this component was compared in the usual diet and the diet prepared and balanced for the sports team. The results revealed that the mean vitamin D consumption was $3.2 \pm 1.6$ $\mu \mathrm{g}$ in the imbalanced diet and $5.9 \pm 2.0 \mu \mathrm{g}$ in the diet customized to sportsmen. Apart from the balanced diet, an additional advantage is exposure to the sun during sports competitions held outdoors. The attention should be turned to rehydrating sportsmen in this period, because this sports activity may lead to dehydration [9].

It is commonly known that proper sportsmen's rehydration is a factor affecting their sports results, enabling the lower loss of mineral components and preventing from a very dangerous phenomenon, dehydration. Defensive players consumed higher amounts of liquids during a day $(1925 \mathrm{ml})$ than offensive players $(1750 \mathrm{ml})$. According to the literature, the mean total amount of liquids consumed (water and drinks for sportsmen), only during the game, that is, a training unit lasting 3 hours, should be about 2200-2600 ml [15]. As it was observed in our study, the results are surprisingly low compared to the recommendations for American football players or soccer players. The differences in the liquids drunk may to some extent depend on the season of the year when the studies were performed. Our study took place in winter, while in the studies compared to ours, trainings were assessed at temperature of about $25^{\circ} \mathrm{C}[15]$.

The amount of sodium consumed in a diet was also essential together with an adequate level of rehydration. Intensive trainings and games cause a huge loss water and sodium with sweat. However, the amount of sodium should not exceed the recommended level, because this may contribute to developing hypertension. In the study from 2014 year, $\dot{Z} y t a$ et al. reported that rugby players consumed on average $3369.5 \pm 1392.8 \mathrm{mg}$ of sodium [26]. The level was lower than our study (a defensive unit, $5195.3 \pm 1650.2 \mathrm{mg}$ and an offensive unit, $4061.2 \pm 1307 \mathrm{mg}$ ), which may suggest excessive consumption of sodium justified only during intensive trainings and games but regarded too high in a usual diet. When discussing a level of sodium consumption, the kind of drink consumed during the physical activity is important as well as highly mineralized water and sports drinks, which usually contain a big quantity of sodium. 
Numerous sportsmen use dietary supplementation. Preparations are often chosen without the adequate knowledge and adjustment to the type of physical activity and players' life style. The discussion about probable supplementation should be based on the evaluation of a usual diet and quantity and the type of physical effort the players undertake. American football players were asked about vitamin and mineral preparations they took and the frequency of their consumption. Offensive players took them more willingly ( $65 \%$ of the study group) and most of them declared their consumption during the whole year. In 2013 year, Casiero et al. concluded that a balanced rich diet did not require additional supplementation with these preparations [4]. If a given component cannot be provided at the adequate level with a diet, preparations supplementing deficiency should be introduced. However, this should be consulted with a physician or a dietician. Dietary supplements should not be chosen, when there are no clear indications [8].

During intensive physical efforts, a huge loss of water and electrolytes occurs, mainly, when trainings and competitions are held at high temperatures. Dehydration is a very dangerous phenomenon that must be prevented from, because this condition affects negatively a player's efficacy in the game field and in critical situations may lead to death. The players of the study group were asked about drinking drinks intended for sportsmen. There is variety of products chosen more frequently than water. In the study group, $96 \%$ of defensive and $90 \%$ of offensive players declared using drinks for sportsmen (isotonic drinks, rehydrating enriched with vitamin and mineral complexes). However, these products were chosen only few times in a week, during longer and more intensive activities. As few as $2 \%$ of the study players reported drinking more than 2 liters of these products daily. In his study, Shirreffs indicated that drinking rehydrating preparations, including isotonic drinks is recommended in long strenuous efforts, when loss of electrolytes, mainly sodium, occurs [21]. This may prevent players from dehydration, mainly, during efforts at high temperatures. It should be underlined that players must be educated about the type of drinks chosen and necessity of drinking water, avoiding sweetened products which contain food coloring. Drinks containing glucose can be consumed during very intensive and long-term efforts.

Lack of time, intensive trainings and desire to build up muscles quickly predispose players to taking sports supplements. These available in the market contain various amounts of nutrients from protein, protein and carbohydrate of the Gainer type to the Carbo type supplements. Sportsmen often ignorantly take the amounts of some nutrients, inadequately to their needs, which may burden excessively their organisms. Protein supplements were chosen most willingly by both players of a defensive (67\%) and offensive (40\%) unit compared to other supplements for sportsmen. Van Loon's study (2013), proved that consumption of protein supplements combined with a rational personalized diet may increase muscles and improve the results among players of strength and endurance sport [25]. This affects beneficially training effectiveness and better results in the sports field. However, a supplement should never replace a balanced diet and be personalized for a sportsperson and their needs as well as completely safe.

Protein and carbohydrate supplements were chosen more rarely, only by $9 \%$ of the examined $(n=3)$. This type of the supplement is characterized by the ratio, on average 50:50 of protein to carbohydrates. They are supplemented with complexes of vitamins and minerals. In the study group, a similar number of players $(n=4)$ took the Gainer type andprotein and carbohydrate supplements. In the study, Nacleiro et al. examined the effect of taking protein and carbohydrate supplements on football players' sports achievements [16]. Each study participant took the preparation consisting of $53 \mathrm{~g}$ of carbohydrates and $14.5 \mathrm{~g}$ of proteins, enriched with $1.5 \mathrm{~g}$ of L-carnitine and $5 \mathrm{~g}$ of L-glutamine. The rise in the fat-free body mass (FFM) of the players and their speed and effort tolerance were assessed in the study. It was established that taking these preparations may contribute to a rise in the fatfree body mass. However, no beneficial effect was proved in the relief of fatigue after intensive trainings, improved speed or fitness during training. Supplements and dietary supplements should not replace a balanced diet. Though, the supplementation of a player's menu with them should be taken into consideration when a caloric value of the food consumed is high and it should be fortified with some nutrients.

The Carbo type supplementation was the last preparation the players were surveyed about in the study. This preparation is used to supplement losses after an intensive physical effort and to rebuild glycogen reserve In our study, 33\% of defensive players and 35\% of offensive players used the type Carbo supplements $(\mathrm{n}=15)$. In the study of Nicholas, it was determined that using carbohydrate preparations may influence beneficially sportsmen's results via an increase in effort fitness, maintenance of proper glycemia level and conserving glycogen during an effort and restoring it in the muscles after the activity [18]. The necessity of the preparation chosen individually for each player during dietary consultation was underlined.

Energizing and concentration - improving products were assessed among the study participants. Coffee was the most frequently chosen energizing product ( $66 \%$ of the surveyed), while guarana, the most rarely chosen (only one player). Energy drinks 
were chosen by $52 \%$ of the surveyed. Tunnicliffe et al. examined 270 players of various sports and assessed consumption of energizing preparations [24]. Caffeine the players took may contribute to the increased fitness endurance and their improved metabolism. The average caffeine consumption was $0.85 \pm 13 \mathrm{mg} /$ $\mathrm{kg}$ in the players. The increased consumption of this substance was not revealed in any sport discipline. Coffee was drunk as frequently as caffeine consumed in the form of a preparation. The highest level of caffeine drunk with coffee was 193-895 mg/day. In the study, it was underlined that excessive consumption of coffee and its preparations may cause gastrointestinal problems among players, sleep disorders and go into interactions with other supplements.

Energizing drinks often contain caffeine or guarana and are enriched with vitamin and mineral complexes. In the study of 2013 year, Del Coso et al. showed consumption of these preparations among rugby players [5]. Sportsmen were given energizing drinks containing caffeine and without it. It was concluded that players taking energizing drinks with caffeine were faster in the field and ran longer distances compared to players from the placebo group. The emphasis was put on the moderate consumption of these preparations as a diet supplementation in the clear conditions as well as monitoring of their influence on the players organisms.

\section{CONCLUSIONS}

1. The defensive formation players were characterized by a higher intake of individual nutrients and more frequent intake of dietary supplements than offensive players.

2. The players' diet should be more balanced. Insufficient supply of energy, water, vitamin D, carbohydrates and dietary fiber has been observed. The consumption of these ingredients should be increased in both formations.

3. The study showed the adequate intake of magnesium, calcium and iron and a significantly higher level of sodium exceeding the norm, which needs to be corrected.

4. A high intake of cholesterol-rich products in both units indicates that players' diet must be modified via reduced consumption of saturated fatty acids and increased consumption of polyunsaturated fatty acids.

5. Players' menus should be more varied including products that are the source of vegetable protein, simultaneously adjusting the intake of animal protein depending on players' individual needs.

\section{Conflict of interest}

The authors declare no conflict of interest.

\section{REFERENCES}

1. Anding R. Oliver J.M.: Football player body composition: importance of monitoring for performance and health. Sports Science Exchange, 2015, 145, 1-8.

2. Berning JR.: Fueling a football team, Sports Science Exchange, 2015; 28, 1-7.

3. Burrows T., Harries S.K., Williams R.L., Lum C., Callister R.: The Diet Quality of Competitive Adolescent Male Rugby Union Players with Energy Balance Estimated Using Different Physical Activity Coefficients, Nutrients. 2016 Sep 7;8(9).

4. Casiero D.: Fueling the rugby player: maximizing performance on and off the pitch. Curr Sports Med Rep,.2013;12:228-33.

5. Del Coso J, Ramírez JA, Muñoz G, Portillo J, GonzalezMillán C, Muñoz V Barbero-Álvarez JC, Muñoz-Guerra $J .:$ Caffeine-containing energy drink improves physical performance of elite rugby players during a simulated match. Appl Physiol Nutr Metab. 2013 Apr;38(4):368-74.

6. Fraczek B, Gacek M, Grzelak A.: Żywieniowe wspomaganie zdolności wysiłkowych w grupie sportowców wyczynowych. Probl. Hig. Epidemiol. 2012, 93(4), 817-818.

7. Gacek M.: Association between self-efficacy and dietary behaviours of American football players in the Polish Clubs in the light of dietary recommendations of athletes. Rocz Panstw Zakł Hig, 2015;66(4): 361-366.

8. Gacek M.: Association between general self-efficacy level and use of dietary supplements in the group of American football players. Rocz Panstw Zakł Hig 2016;67(1): 31-36.

9. Garrido G., Webster AL., Chamorro M.: Nutritional Adequacy of Different Menu Settings in Elite Spanish Adolescent Soccer Players, Int J Sport Nutr Exe, 2007, 17, 421-432.

10. Imamura H, Iide K, Yoshimura Y, Kumagai K, Oshikata R, Miyahara K, Oda K, Miyamoto N, Nakazawa A.: Nutrient intake, serum lipids and iron status of colligiate rugby players, J Int Soc Sports Nutr. 2013; 10: 9.

11. Jäger R, Kerksick CM, Campbell BI, Cribb PJ, Wells SD, Skwiat TM, Purpura M, Ziegenfuss TN, Ferrando AA, Arent SM, Smith-Ryan AE, Stout JR, Arciero PJ, Ormsbee MJ, Taylor LW, Wilborn CD, Kalman DS, Kreider RB, Willoughby DS, Hoffman JR, Krzykowski $J L$, Antonio J.: International Society of Sports Nutrition Position Stand: protein and exercise. J IntSoc Sports Nutr. 2017 Jun 20;14:20.

12. Jarosz M.: Normy żywienia dla populacji polskiejnowelizacja. Instytut Żywności i Żywienia, Warszawa 2017.

13. Jaskulska E., Jastrzębski Z.: Znaczenie suplementacji witaminą D3 u człowieka w spoczynku oraz wysiłku fizycznym, Teoria i praktyka wychowania fizycznego i sportu, 2013,81-91.

14. Lundy B, O'Connor H, Pelly F, Caterson I.: Anthropometric Characteristics and Competition Dietary Intakes of Professional Rugby League Players. International Journal of Sport Nutrition and Exercise Metabolism, 2006,16,199-213. 
15. Montain S.J.: Hydration recommendations for sport 2008. Curr. Sports Med. Rep., 2008, 4,187-192.

16. Naclerio F., Larumbe-Zabala E., Cooper R., Allgrove J., Earnest CP.: A Multi-Ingredient Containing Carbohydrate, Proteins L-Glutamine and L-Carnitine Attenuates Fatigue Perception with No Effect on Performance, Muscle Damage or Immunity in Soccer Players, PLoS One.,2015, 27;10(4)0125188.

17. Nicholas C.: Legal nutritional supplements during a sporting event. Essays Biochem. 2008;44:45-61.

18. Nutrition and Athletic Performance, Medicine \& Science in Sports \& Exercise, American College of Sports Medicine, 2009, 41:3, 709-710.

19. Potgieter S., Visser J., Croukamp I., Markides M., Nascimento J., Scott K.: Body composition and habitual and match-day dietary intake of the FNB Maties Varsity Cup rugby players, SA J. Sports Med, 2014;26:35-43.

20. Rodriguez NR., DiMarco NM., Langley S.: American Dietetic Association; Dietitians of Canada; American College of Sports Medicine, "Position of the American Dietetic Association, Dietitians of Canada and the American College of Sports Medicine : Nutrition and athletic performance", J. Am. Diet. Assoc., 2009;109(3):509-27.
21. Shirreffs SM, Hydration: Special issues for playing football in warm and hot environments. Scand J Med Sci Sports 2010,20: 90-94.

22. Szponar L., Wolnicka K., Rychlik E.: Album fotografii produktów i potraw, IŻŻ, Warszawa, 2000.

23. Tooley E, Bitcon M, Briggs MA, West DJ, Russell M: Estimates of Energy Intake and Expenditure in Professional Rugby League Players International journal of Sports Science \& Coaching, 2015;2:3551-560.

24. Tunnicliffe JM, Erdman KA, Reimer RA, Lun V, Shearer $J .:$ Consumption of dietary caffeine and coffee in physically active populations: physiological interactions. Appl Physiol Nutr Metab. 2008;33(6):1301-10.

25. Van Loon LJC.: Is there a need for protein ingestion during exercise?. Sports Science Exchange, 2013;26,109:1-6.

26. Żyła K, Stachura J, Różańska D.: Assessment of dietary intake and anthropometric parameters among rugby union players., Cent. Eur. J. Sport. Sci. Med., 2014;8:4:35-45.

Received: 21.08.2018

Accepted: 05.02.2019

This article is available in Open Access model and licensed under a Creative Commons Attribution-Non Commercial 3.0.Poland License (CC-BY-NC) available at: http://creativecommons.org/licenses/by-nc/3.0/pl/deed.en 